Special issue of the International Conference on Computational and Experimental Science and Engineering (ICCESEN 2014)

\title{
Application of GIS for Predicting Quality of Underground Water for Drinking
}

\author{
M. GÜNAL* AND A. KÖSEN \\ Gaziantep University, Civil Engineering Department, Gaziantep, Turkey
}

\begin{abstract}
Gaziantep is located at the south-east part of Turkey. Drinking water needs of Gaziantep city are increased because of population in last decade. Some amounts of drinking water are supplied to Gaziantep from underground. Because of large amount of industrial areas and settlement, quality of ground water is decreased in years. Therefore governors of the city should know which part of the city has a potential of having good quality of drinkable underground water. In this study, 9 wells in the city centre area of Gaziantep city are determined and water samples were taken from these wells. Then water samples were analyzed in the laboratory of GASKİ (Gaziantep Water and Sewage Management). The laboratory results of underground water from each well are entered to ArcGIS program with the digital elevation map of Gaziantep to predict the quality of the underground water of Gaziantep. The ArcGIS program produced quality maps of drinkable water in Gaziantep. These maps show the dynamic and static water levels in the well, $\mathrm{pH}$ level, bromide, sulfate, free chlorine, hardness, turbidity, nitrate, and fluoride. This study shows that ArcGIS program is very useful tool to make the quality maps of groundwater for a specific area.
\end{abstract}

DOI: 10.12693/APhysPolA.128.B-107

PACS: $92.40 . \mathrm{kc}$

\section{Introduction}

Groundwater is the source of drinking water for many people around the world. Groundwater could be contaminated naturally or because of numerous types of human activities. Residential, municipal, commercial, industrial, and agricultural activities can all affect groundwater quality. Groundwater contamination is the reason of low quality drinking water, loss of water supply, high clean-up cost, high cost for alternative water supplies, and/or potential health problems. A wide variety of materials have been identified as contaminants in groundwater.

Groundwater contamination by nitrates is a worldwide problem mainly related to the excessive use of fertilizers in intensive agriculture. According to the Turkish Standards Institute (TSE-266) [1], the World Health Organization (WHO) and the European Community (EC), the maximum contaminant level (MCL) of nitrate is given to be $50 \mathrm{mg} / \mathrm{L}$ whereas the US Environmental Protection Agency (EPA) allows for only $44.27 \mathrm{mg} / \mathrm{L}$ in drinking water. On the other hand, both Turkish Standards Institute (TSE-266) and European Community (EC) describe the guide level (GL) of nitrate as $25 \mathrm{mg} / \mathrm{L}$.

Vinten and Dunn [2] studied the effects of land use on temporal changes in well water quality. The nitrate concentration in discharge from the Balmalcolm borehole in Scotland was reported to have steadily increased from $19.2 \mathrm{mg} / \mathrm{L}$ in the early $1970 \mathrm{~s}$ to $47 \mathrm{mg} / \mathrm{L}$ in 1998 . Levallois et al. [3] studied groundwater contamination

*corresponding author; e-mail: gunal@gantep.edu.tr through nitrates associated with intensive potato culture in Québec, Canada. The data analysis was carried out by combining GIS (MapInfo) and statistical methods to test hypotheses about the spatial relationship between measured nitrate concentrations and their immediate environment. D'Agostino et al. [4] described a spatial and temporal study of nitrate concentration in the aquifer of the Lucca Plain, central Italy.

\section{Methodology}

In this study, 9 wells in the city centre area of Gaziantep city are determined and water samples were taken from these wells. Then water samples were analyzed in the laboratory of GASKI. The laboratory results of water from each well are then entered to the ArcGIS program with the digital elevation map of Gaziantep to make groundwater quality map of Gaziantep by using the laboratory results. The ArcGIS program produced quality maps of drinkable underground water in Gaziantep. These maps show the dynamic and static water levels, $\mathrm{pH}$ level, bromide, sulfate, free chlorine, hardness, turbidity, nitrate, and fluoride level in groundwater.

\subsection{Digital elevation model (DEM)}

DEM of Gaziantep city centre was obtained from Gaziantep Metropolitan Municipality. DEM is the starting point in this study. There are 9 wells which are used to supply drinking water to the city. The names of these wells are added to ArcGIS computer program as shown in the following Fig. 1.

Main purpose of this study is to prepare quality map of underground water. Therefore, the parameters of static and dynamic levels, $\mathrm{pH}$, electrical conductivity, turbidity, cyanide, bromide, chloride, fluoride, chlorine, hardness and nitrite is added to the program with well name. 


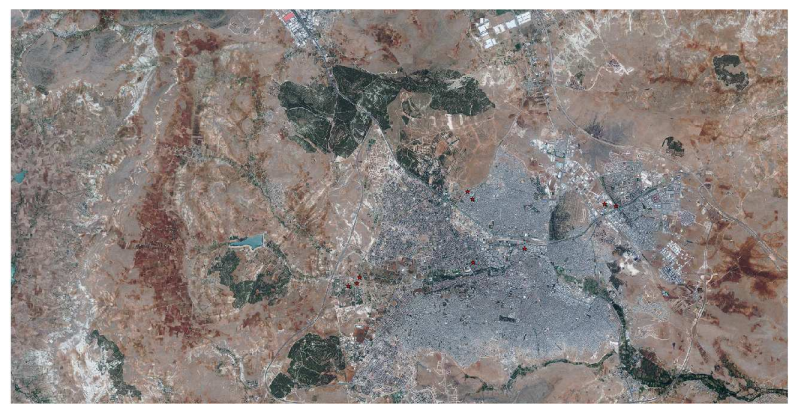

These parameters are entered to a table in ArcGIS program that is given in Table. The coordinates of the wells are also added to Table. After adding all the parameters which are given in Table, the spatial analysis tool of MAPINFO program was run to predict the distribution of the parameters in Gaziantep city centre. The obtained maps of the parameters are given and discussed in the next part.

Fig. 1. DEM of Gaziantep City.

TABLE

Properties of underground water. The abbreviations: elevation - E, static water level — SWL, dynamical water level - DWL, turbidity $-\mathrm{T}$, color (in $\mathrm{Pt}-\mathrm{Co}$ scale) $=5$, chloride $-\mathrm{C}$, free chloride $-\mathrm{FC}$, electrical conductivity $-\mathrm{EC}$, nitrite $-\mathrm{Ni}$, ammonia $=0 \mathrm{mg} / \mathrm{l}$, hardness $-\mathrm{H}$, smell $=$ odorless, taste $=$ normal, nitrate $-\mathrm{Na}$, sulfate $-\mathrm{S}$, sodium $-\mathrm{So}$, cyanide $-\mathrm{Ca}$, fluoride $-\mathrm{F}$, bromide - B.

\begin{tabular}{|c|c|c|c|c|c|c|c|c|c|c|c|c|c|c|c|c|c|c|}
\hline \multirow{2}{*}{ Well names } & \multicolumn{2}{|c|}{ Coordinates } & $\mathrm{E}$ & SWL & DWL & \multirow{2}{*}{$\mathrm{pH}$} & \multirow{2}{*}{$\begin{array}{c}\mathrm{T} \\
{[\mathrm{NTU}]}\end{array}$} & $\mathrm{C}$ & $\mathrm{FC}$ & \multirow{2}{*}{$\begin{array}{c}\mathrm{EC} \\
{\left[\frac{\mathrm{nS}}{\mathrm{cm}}\right]}\end{array}$} & \multirow{2}{*}[\begin{array}{c}{\mathrm{Ni}}\\
{[\frac{\mathrm{mg}}{\mathrm{l}}]}\end{array}]{} & \multirow{2}{*}{$\mathrm{H}$} & $\mathrm{Na}$ & $\mathrm{S}$ & So & $\mathrm{Ca}$ & \multirow{2}{*}{$\begin{array}{c}\mathrm{F} \\
{[\mu \mathrm{g} / \mathrm{l}]}\end{array}$} & \multirow{2}{*}{$\begin{array}{c}\text { B } \\
{[\mathrm{mg} / \mathrm{l}]}\end{array}$} \\
\hline & North & East & & [m] & & & & {$[\mathrm{mg}$} & & & & & \multicolumn{4}{|c|}{$[\mathrm{mg} / \mathrm{l}]$} & & \\
\hline $\begin{array}{c}\text { Haraf } \\
\text { (Ddeğirmiçem) }\end{array}$ & 37.0666 & 37.3635 & 840 & 5 & 8.15 & 7.74 & 0.1 & 27.458 & 0.3 & 70.3 & 0.001 & 3.2 & 30.158 & 32.73 & 6.034 & 0.032 & 0.196 & 0.023 \\
\hline Kadıdeğirmeni-1 & 37.0601 & 37.3151 & 881 & 26.02 & 31.6 & 7.36 & 0.37 & 10.39 & 0.3 & 46.1 & 0.002 & 2.32 & 15.759 & 11.135 & 7.141 & 0.006 & 10.39 & 0.015 \\
\hline Kadıdeğirmeni-2 & 37.062 & 37.3162 & 892 & 18.2 & 21.1 & 7.39 & 0.11 & 9.912 & 0.3 & 44.7 & 0.014 & 2.06 & 11.712 & 8.697 & 6.209 & 0.006 & 0.2 & 0.014 \\
\hline Fen Lisesi & 37.0592 & 37.3113 & 876 & 28.75 & 41.3 & 7.63 & 0.16 & 6.426 & 0.3 & 42.1 & 0.001 & 2.02 & 11.79 & 7.907 & 4.622 & 0.006 & 0.186 & 0.015 \\
\hline İtfaiye & 37.0878 & 37.3639 & 870 & 37.2 & 55.9 & 7.14 & 0.1 & 0 & 0.3 & 63.3 & 0 & 2.79 & 0 & 0 & 0 & 0 & 0 & 0 \\
\hline Zeytinli & 37.0902 & 37.3618 & 880 & 42.75 & 49.1 & 7.68 & 0.12 & 18.353 & 0.3 & 49.1 & 0.001 & 2.3 & 16.93 & 5.7 & 12.36 & 0.01 & 0.171 & 0.013 \\
\hline Gazikent & 37.0847 & 37.4237 & 825 & 30.05 & 35.4 & 7.34 & 0.22 & 0 & 0.3 & 44.7 & 0 & 2.26 & 0 & 0 & 0 & 0 & 0 & 0 \\
\hline Göllüce & 37.0854 & 37.4189 & 823 & 13.3 & 16.75 & 7.22 & 0.08 & 25.39 & 0.3 & 51.4 & 0 & 2.41 & 27.55 & 15.77 & 11.7 & 0.064 & 0.18 & 0 \\
\hline Nizip Caddesi & 37.0708 & 37.3852 & 825 & 4.3 & 13.6 & 7.31 & 0.61 & 0 & 0.45 & 0 & 0 & 0 & 0 & 0 & 0 & 0 & 0 & 0 \\
\hline
\end{tabular}

\section{Results and discussion}

\subsection{Bromide level}

In the east side of Gaziantep at Gazikent, Aydınlar and Nizip district the bromide level is very low. In the north of the city at the district of fire station the bromide level is also very low. At Zeytinli district the bromide level is low. In the west of city at the district of Kadıdeğirmeni and around the Science High School the bromide levels are really intense. At the south of the city in a $175 \mathrm{~m}$ radius the bromide levels are also very high (Fig. 2).

\subsection{Chloride level}

Nizip district in a $300 \mathrm{~m}$ radius chloride level is really low. At Aydınlar district in a $200 \mathrm{~m}$ radius the chloride level is really intense. At the west of the city in the fire station district the chloride level is really low. At Zeytinli district the chloride levels are really low in a small area. At the west of city in Science High School and Kadıdeğirmeni district the chloride levels are normal. In the south of the city at Haraf district in a $275 \mathrm{~m}$ radius the chloride levels are really intense (Fig. 2).

\subsection{Cyanide level}

In the east of Gaziantep at Gazikent, Nizip, Zeytinli, Kadıdeğirmeni and Science High School district in a $200 \mathrm{~m}$ radius the cyanide levels are really low. At Aydınlar district in a $200 \mathrm{~m}$ radius the cyanide levels are really intense. At Haraf and Gazikent district the cyanide levels are at normal phase (Fig. 2).

\subsection{Fluoride level}

In the city of Gaziantep at Science High School and Kadıdeğirmeni-2 district the fluoride level is really intense. At Kadıdeğimeni-1 district the fluoride levels are really low. At Zeytinli, Firestation, Haraf, Nizip, Aydın and Gazikent district the fluoride levels are also really low (Fig. 3).

\section{5. pH level (hardness of water)}

In the city of Gaziantep at Haraf district the hardness of the water is intense. At the fire station district, it is a little lower. At Aydınlı, Kadıdeğirmeni, Science High School and Zeytinli district the hardness of the water is 

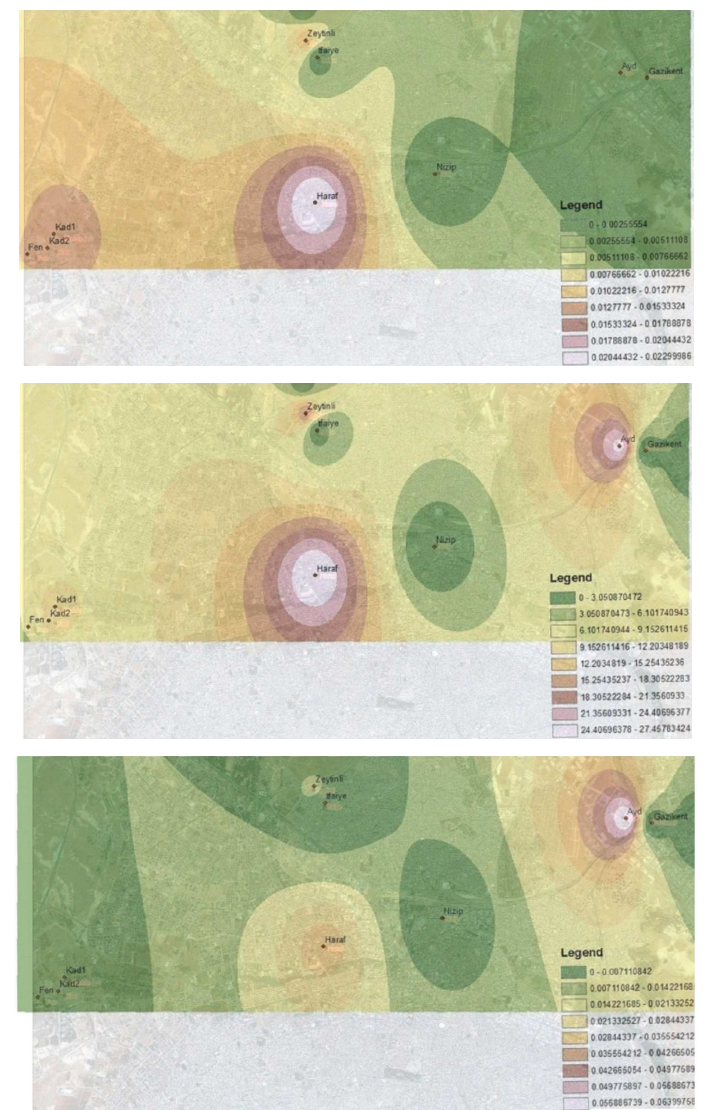

Fig. 2. Bromide (top), chloride (middle), and cyanid (bottom) level.

higher than in fire station district. At Nizip district, the hardness of the water is almost zero (Fig. 3).

\subsection{Nitrate level}

In the city of Gaziantep at Haraf district nitrate levels are really intense. At Aydın district, the nitrate levels are lower than Haraf district. At Kadıdeğirmeni, Science High School and Zeytinli district the nitrate levels are lower than Aydin district. At fire station, Nizip, Gazikent district the nitrate levels are also really low (Fig. 3).

\section{Conclusion}

North and north-eastern part of the city of Gaziantep, the turbidity, sulfate, and nitrate levels are the lowest. Towards the south of the city, the level of sodium is decreasing and according to this the level of acid and alkali increases. All of the parameters are proper for TSE-266. The effects of nitrite in human health in long term are caused by permanent damage. Because of this, it is very important to watch the chemical reactions of nitrite converting to nitrate.
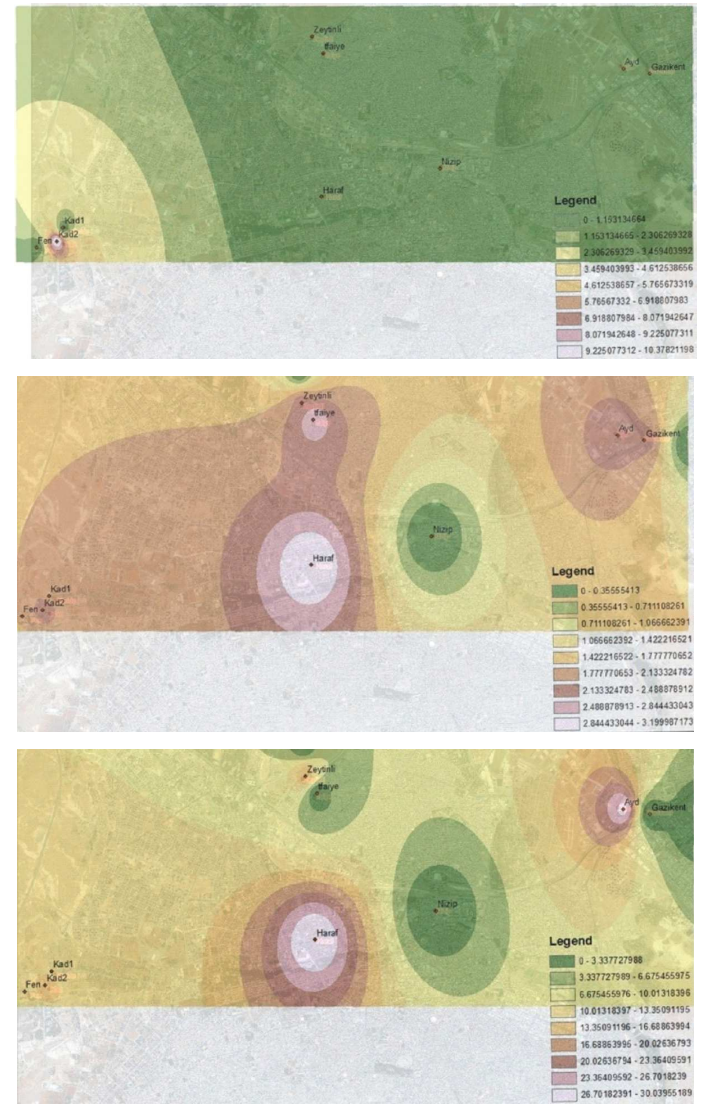

Fig. 3. Fluoride (top), hardness (middle), and nitrate (bottom) level.

\section{References}

[1] TSE, Drinking Water Turkish Standards, 1997, Turkish Standards (TSE-266), Ankara.

[2] A.J.A. Vinten, S.M. Dunn, Sci. Total Environm. 265, 253 (2001).

[3] P. Levallois, M. Thériault, J. Rouffignat, S. Tessier, R. Landry, P. Ayotte, M. Girard, S. Gingras, D. Guavin, C. Chiasson, Sci. Total Environm. 217, 91 (1998).

[4] V. D'Agostino, E.A. Greene, G. Passarella, M. Vurro, Environm. Geol. 36, 285 (1998). 